\title{
TITLE:
}

\section{YANOSUKE SAIKA (1888-1957)}

$\operatorname{AUTHOR}(S)$ :

Miyadi, Denzaburo

\section{CITATION:}

Miyadi, Denzaburo. YANOSUKE SAIKA (1888-1957). PUBLICATIONS OF THE SETO MARINE BIOLOGICAL LABORATORY 1957, 6(2): 125-126

\section{ISSUE DATE:}

$1957-12-25$

URL:

http://hdl.handle.net/2433/174584

RIGHT: 


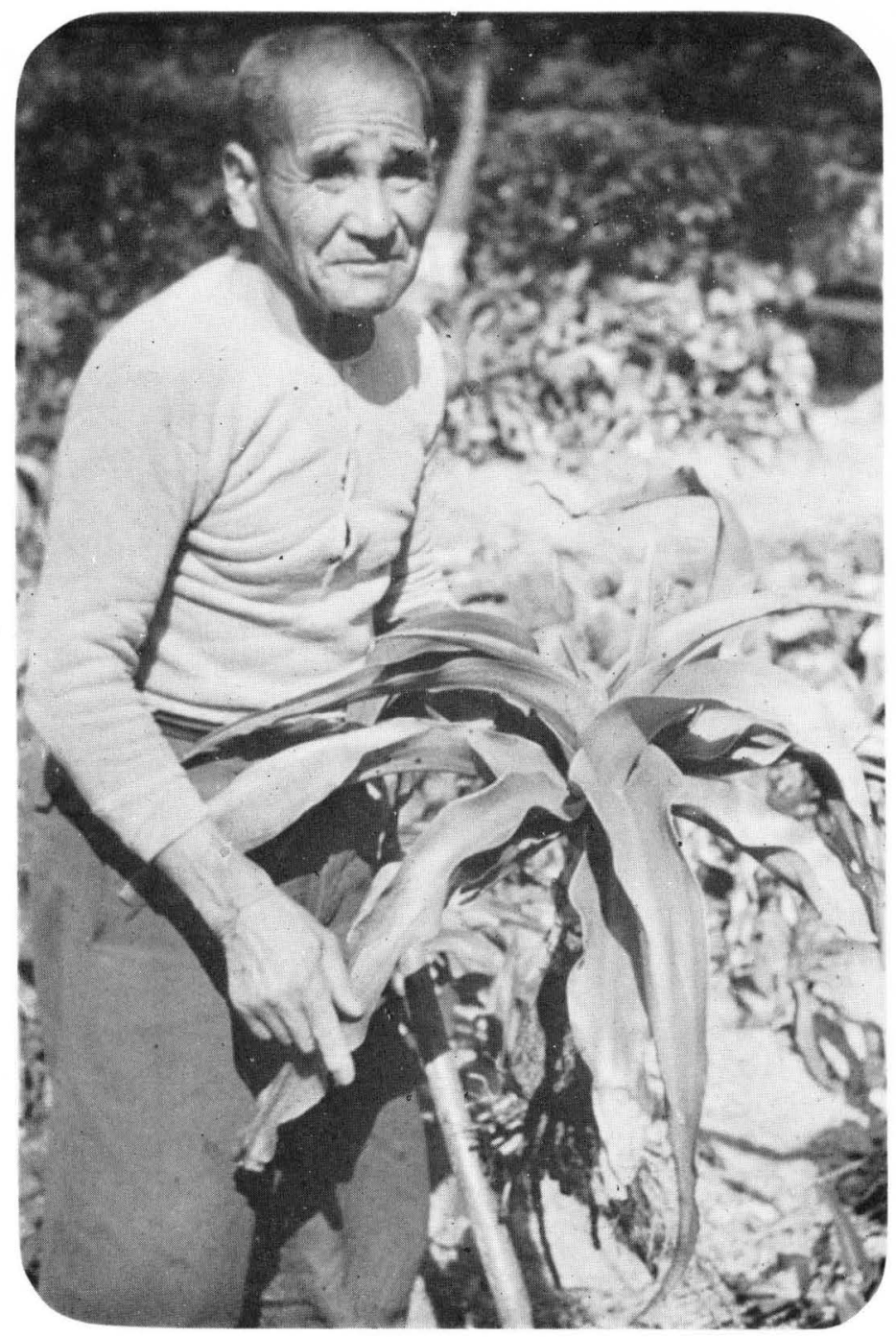

Yanosuke SAIKA

(1888-1957) 


\section{YANOSUKE SAIKA}

(1888-1957)

Mr. Yanosuke SAIKA was born on the 11th of March, 1888, at the village of Seto, now the town of Sirahama, where the Seto Marine Biological Laboratory is located. After finishing his schooling at the primary school, he engaged in the shipping which was the business of his family. From this experience as well as the naval service he acquired the knowledge on the sea both of the Japanese coast as well as abroad.

When the Kyoto Imperial University decided in 1921 to establish a marine station at Seto, he was recommended as the supervisor of the construction work, and continued his service at the Laboratory since its official opening in 1922 as the captain of the surveying boat Nytusin-maru and the collector. Being a keen observer, Mr. SAIKA accumulated, by his own effort as well as by absorbing from researchers, wide and precise knowledge on the fauna and flora of the surrounding sea of the Laboratory. He was so well aquainted with the habitat and the life history of both animals and plants, that he could supply the specimens for the research and the aquarium exhibition as readily as a gardener could pick the flowers from his own garden. He was also a good and reliable advisor to be first consulted by students to start their marine ecological works. We estimated him as LoBianco had been by visitors of the Zoological Station at Naples, Italy.

As a keeper of the Aquarium, he was not only an excellent collector but took care of the animals with love. He drained once every day the aquarium which kept the sea-anemone Actinia equina, for the comfort of this inhabitant of the tidal zone, and it thus lived in good condition for a long time.

The Laboratory is situated on so-called the main street of typhoons, and it required a constant care, both during the daytime and at night, as well as hard work to keep boats in safety. It was chiefly due to his effort that no damage occurred either on persons or boats during his service at the Laboratory. We were in confidence that the boats and collecting equipments were always at the condition of stand-by both for the resident staffs and visiting researchers.

Publ. Seto Mar. Biol. Lab., VI (2), 1957. (Article 8) 
He won official commendations once at the 50th Anniversary of the Kyoto University on the 25th of October, 1947, and twice at the 30th Anniversary of the Seto Marine Biological Laboratory on the 18th of October, 1952.

After his retirement from the office on the 31st of March, 1952, because of an old age, he remained as the honorary attendant and lived near the Laboratory, to which he showed unchanged affection. All visiting researchers enjoyed the talk with him on good old times as well as hard days in the history of the Laboratory. He was in good health both physically and mentally, and it was an astonishment of his friends that he should die of cancer so early, on the 10th of February, 1957, at the age of 69 . Now he sleeps with his fathers at Hongakuzi Temple, well known as the 'Shell-Temple' for its collection of marine shells.

\section{Denzaburo MiYADI}

Director 